\title{
The Private Sector and Privatization in Social Services
}

\section{Is the Washington Consensus 'Dead'?}

\author{
SANTOSH MEHROTRA \\ UNDP Regional Centre for Asia and Pacific, Bangkok \\ ENRIQUE DELAMONICA \\ Policy Analyst, Global Policy Section, UNICEF, New York, USA
}

A B STRACT One of the most significant developments in the 1990s in social policy in developing and transition countries has been the growth of privatization in health, education and water services - three basic services, which involve most of the Millennium Development Goals (MDGs). Welfare pluralism was very much a core element of the Washington Consensus. Despite the talk of the Washington Consensus being 'dead for years', the international financial institutions have pushed for welfare pluralism in social services since the 1990s. This article critically scrutinizes the arguments and evidence that have been made in favour of greater private sector participation in these services. The article addresses what role the private sector could or should play in these services and is, thus, driven by practical policy concerns. For reasons of space, this article does not address the non-profit or nongovernmental organization (NGO) provision of basic social services (which, in most countries, is quite small in size).

KEYWORDS global education policy, global health policy, global water policy, privatization, Washington Consensus 


\section{Introduction}

In the last two decades of the 20th century there have been reversals from the policies of universal provision of basic services by the state. These reversals have been characterized by efforts in social policies to expand the use of market mechanisms such as insurance, private pensions and user charges. This process has also been accompanied, at least in developing countries, by greater acceptance of the role of the private sector (as well as civil society and community organizations) as elements of a formal system of welfare provision.

This welfare pluralism (i.e. the idea that the state should not be the only, or even the primary, financier and provider of basic social services) was born out of the conservative tide of attacks on the welfare state in industrialized countries and the structural adjustment programmes in developing countries. This welfare pluralism takes the clock back to an earlier historical era when social advances and capabilities enhancement proceeded at a much slower pace than during the decades of state-led welfare provision.

In much of Europe, private providers dominated health, education and water services in the first half of the 19th century. But these services were limited. In the second half of the 19th century public financing and provision became predominant. Indeed, only when governments intervened did these services, especially health insurance and compulsory schooling, become universal in Western Europe and the northern USA - in the last quarter of the 19th and first half of the 20th century. After World War II, and especially after decolonization in Africa and Asia, similar (albeit much more limited) social policies were implemented. ${ }^{1}$ Industrialized countries, since 1980, started to experiment with more targeted interventions to reach the unreached, and then public-private partnerships to serve different markets - depending upon the nature of services in different sectors. However, there is no reason to believe that developing countries should embark on a path of extensive privatization in social services, especially as large parts of their populations are still not covered by the most basic education and health services.

The case for universalism in the provision of basic services in developing countries has already been agreed in multiple summits of governments over the last decade and a half. Who will provide these basic services? According to the Washington Consensus the answer is clear: the role of the state should be kept delimited. ${ }^{2}$ The question is whether this advice from the Washington Consensus is still relevant. Some authors (e.g. Stiglitz, 1998) argue for a Post Washington Consensus while others (e.g. Fine, 2001; Standing, 2000) believe the international financial institutions (IFIs) have not really changed their recommendations. This debate is mainly about macro-economics. In this article we address this question from the point of view of social policy and more specifically the provision of basic social services. This topic, of course is important in its own right as well as because of the impact of these policies on reaching the Millennium Development Goals (MDGs). The World 
Development Report 2004 was devoted to this issue. The latter explicitly rejuvenated the Washington Consensus by constraining state involvement in the social sectors through an ' 8 sizes fit all' model which based on 'scientific and technical analysis' ${ }^{3}$ determines which services should be provided by the state (very few) and which ones through market type mechanisms (most of them). ${ }^{4}$ Even immunization and public health campaigns are said to be left out of the states' purview. ${ }^{5}$

In section 1 we discuss why private provision might have increased in developing countries in recent decades and in section 2 we present a framework of analysis. The following three sections discuss the role of private providers of social services - first in education (section 3), then health (section 4) and then in water and sanitation (section 5). The narratives in the three are rather different: ${ }^{6}$ as the state has failed to respond with quality schooling in many low-income countries, the private sector has expanded. But in health services and water services, there has been a deliberate push towards privatization. An appraisal of the current impetus towards privatization in social services from the donor community is found in section 6. Section 7 concludes the article.

\section{Why has Private Provision Increased?}

Three factors seem to have driven the private sector's growing role in health and education, and the push to privatize water and hospital services: lack of government resources, low-quality public provision and pressure to liberalize the economy. In other words, compulsions of various kinds have tended to drive the growing role of the private sector in social services in developing countries, rather than any particular merits that flow intrinsically from private provision of social services.

One of the reasons why governments have been unable to provide social services effectively or fund large investments in infrastructure is their budget deficits. They grew so large as the developmental state expanded its role excessively in the economy, especially its productive sectors, that many governments were forced to adopt structural adjustment programmes, based on International Monetary Fund (IMF) and/or World Bank lending.

In some cases, such as domestic water and sanitation (and irrigation and energy) the problem of limited government funds has been compounded by distorted tariff structures. State-owned enterprises often charge tariffs that are too low to recoup costs, and user failures (especially well-connected or ordinary middle-class users) to pay tariffs are often overlooked. This approach is the hallmark of inequity as it subsidizes the non-poor at the expense of the poor, as it is the latter that lack access. As urban populations increase, fiscally constrained local authorities cannot expand services to cover them, especially when peri-urban areas are uncovered to begin with. Everyone is a loser - as water services decline in quantity and quality in 
middle-class neighbourhoods, and at the same time fail to reach new poor neighbourhoods.

Second, the lack of resources is linked to a weak record of public provision in many countries. According to Kremer et al. (2004), in India, Bangladesh, Papua New Guinea, Indonesia, Peru, Ecuador, Zambia and Uganda teacher absence ranges from $13 \%$ to $26 \%$ of teachers. Poorly paid public sector doctors often supplement their incomes by selling drugs intended for free distribution (Van Lerberghe et al., 2002). As a result poor (and non-poor) people are forced to use private providers, because such providers are more accessible and often dispense drugs as part of their consultations (unlike government facilities, where drugs may not be available [Rohde and Viswanathan, 1995]). To access water, poor people often have to pay exorbitant prices for it from private tankers run by small vendors. Most residents of South Asian cities receive water through the municipal pipes for only a couple hours at a time, and not every day (Leipziger and Foster, 2003).

The third source of encouragement to private provision and privatization came from the international financial institutions and from donors. The social services are seen as 'frontier areas' in privatization (see section 6).

However, a very important reason for government financing and provision is that it may be difficult to trigger the synergies among health, family planning, water and sanitation, nutrition and education inputs and outcomes without simultaneous investment in each. Interventions in basic social services (health, nutrition, water and sanitation, education) complement each other. Each intervention has ramifications that lie outside its 'sector'. This is different from the existence of an externality, although they are of course present. Unlike the traditional treatment of externalities, which are usually exceptions and consequently can be dealt with (at least theoretically) by (re)specifying property rights, these interactions are pervasive. Moreover, they do not just affect another sector, they all impinge on each other, resulting in a mesh of interactions. In other words, it is a multidimensional synergetic system. Hence the need for the public sector to step in and finance these services.

If the investment is left to the private sector, there is much greater risk of coordination failure and lower efficiency than if the state was to provide the services, instead of merely financing them. This is not say that private provision (and financing) should not play a complementary role in some nonessential services; we are only making the case here for a lead role for the state.

In this context, it is important to distinguish government financing from government provision. Additional reasons for the latter include:

- Economies of scale, e.g. water supply is in many ways a natural monopoly and provision by more than one agency (public or private) would result in higher unit costs. Thus, a single provider makes more sense. That the single provider should cover total costs may be crucial; ${ }^{7}$ that it should earn profits is not so obvious. 
- Practical contracting problems are particularly severe. As there is asymmetric information between the government (the financier) and the private party (the provider), the society-wide goals may be difficult to achieve. For instance, if reducing inter-regional inequalities was a goal of government, the state would have to supply these services in rural areas; contracts with private providers would be difficult to establish and even thornier to monitor and enforce.

- Basic social services are human rights, as defined by the Convention on the Rights of the Child and the Covenant on Economic, Social and Cultural Rights. If the private sector is unwilling or unable to provide these services, the rights of citizens imply a corresponding obligation on the part of the state to fill the gap. However, a 'provider of last resort' could be underfunded and suffer from high unit costs or low quality - thus universal provision is more efficient.

\section{Analytical Framework}

Table 1 tries to capture our framework of discussion on the roles of state and private provision. The basic premise is that they belong in two different conceptual categories, with contrasting or opposing values, but constituting a continuum in the actual implementation in the real world. Moreover, both of them are liable to be abused and misapplied.

The basic premise of state-led provision of basic social services, besides the practical ones (e.g. synergies, lower unit costs, mentioned above), is that society, through its political representatives, channels collective action (taxing itself to obtain resources and hire people) to deliver the goods that should be provided to everybody. Thus, the historical experience of now-industrialized countries and the 'high achieving' countries suggests that basic education and primary health were early on recognized as particular services to be provided free (Mehrotra, 1997). Thus, no distinctions are made among recipients, everybody is equal. Obviously, this builds upon and goes beyond the

ТА В LЕ I Comparison of two alternative systems for social service delivery

\begin{tabular}{|c|c|c|c|}
\hline & State led provision & & Market led provision \\
\hline Distortion & Benefits & Benefits & Distortion \\
\hline $\begin{array}{l}\text { Co-opted and } \\
\text { abused by elites }\end{array}$ & Equity & Pluralism & Inequality \\
\hline Sclerosis & Social integration & $\begin{array}{l}\text { Sensitivity to } \\
\text { minorities' concerns }\end{array}$ & Social Exclusion \\
\hline Totalitarianism & Lower unit cost & Innovation & $\begin{array}{l}\text { Conflict/survival } \\
\text { of the fittest }\end{array}$ \\
\hline
\end{tabular}


traditional notion of 'merit good'. This promotes social integration, as enjoying the services does not depend on political favours or the ability to pay, but only based on citizenship. Political cohesion and nation building are also enhanced this way.

When these services can be bought in a market, as if they were candy or cigarettes, a very important shared value is lost. Nevertheless, there might be some reasons for loosening the reins of state provision. This is clearest in education. Some groups (say for religious reasons) might want to have the freedom to teach their children in a certain way. As long as this is not disruptive of the social fabric (e.g. preaching hate-mongering or violence), this could be allowed to promote pluralism and protect minorities. Also, as education is complex, at any given time parents might prefer certain pedagogical tools. State schools cannot be changing rules and curricula all the time, but outlets for innovation in private schools, again within the general guidelines mentioned above, could also be allowed.

Second, the advantages of the state-led and market-led approaches can be trumped if distortions occur. For state-provision, the one most commonly mentioned in the literature in recent years is the inequity that emerges as public spending is concentrated in well-to-do areas, creating or reinforcing inequities. Also, lack of innovation deriving from bureaucratic inertia can lead to sclerosis and declining quality. Obviously, the solution for these problems is not privatization, but an engaged civil society that participates in the political decision process (see Mehrotra, 2002; Tendler, 1997). Moreover, unfettered markets also have their pitfalls and distortions. When the services are offered only to those who can pay or are willing to pay more, inequality increases. Markets, by their very nature are a rationing mechanism, which means that applying commercial values in the provision of basic social services will necessarily result in social exclusion. This, in turn, can generate resentment and social conflict.

In practice, in most countries, there are no complete state monopolies in the provision of social services. The important point is that even if some room is allowed to private providers, they, or their practices, ${ }^{8}$ should not be dominant. When state provision is not feasible or pluralism is considered an important value, state guidelines and regulations are vital to ensure universality and equality in access to basic social services that in turn promote social cohesion and individual capability enhancement.

As the examples and the analyses that follow show, countries, their leaders and, most importantly, their citizens need to keep these differences in mind when evaluating the role proposed/pushed by the Washington Consensus for the private sector in the provision of basic social services. 


\section{Education}

This section begins by recalling the role of the public and private sectors in education in the now industrialized countries in a comparable period of development in the 19th century. It goes on to examine the role of the private sector in the so-called high-achieving developing countries, which made remarkable health and education progress early in their development process.

A multitude of scholars who have examined the rise of schooling in the advanced capitalist countries agree on the predominant role of the state in ensuring universal schooling (Fishlow, 1966; Green, 1990; Sanderson, 1983; Stephens, 1998). 'The history of mass primary and secondary schooling is dominated by the rise of public, not private supply. No high-income OECD [Organisation for Economic Co-operation and Development] country has relied solely on private demand and supply in education, least of all in primary schooling' (Lindert, 2004: 88).

There were a number of measures that were common to the industrialized countries (USA, Prussia/Germany, France and the UK) in the latter half of the 19th century:

- First, the state created a public system of schooling that was financed from taxes, and a rising tide of public investment in education was evident in all of them.

- Second, the state worked gradually towards the elimination of tuition fees.

- Third, the state made elementary education compulsory.

- Fourth, varying degrees of centralization emerged, with bureaucracies to run the public school system, including the training of teachers and the creation of an education department.

These measures were usually taken in the second half of the 19th century, except in Prussia, Holland and Switzerland in Europe, and north-east USA, which were early starters. Countries that developed state-funded systems of public education early on (for instance, Prussia and the northern USA), ${ }^{9}$ achieved the higher levels of enrolment and literacy. Countries (for instance, England and Wales) with no public system until quite late fared worse in terms of those indicators.

The source of some of the private supply was philanthropic or ecclesiastical, but it was the state that subsidized education even in the laggard UK. More important, it was where local government ensured tax-financed public schooling that mass schooling became possible. What is also clear is that there was no crowding out effects of the increase in public education spending on private schooling. In other words, the rise of tax-based public schooling did not displace private schooling.

Similarly, one can ask the question for high-achieving developing countries: how significant was the private sector in universalizing primary education in 
the high-achieving developing countries? It is not as though the industrialized countries were unusual in that the state played a predominant role in universalizing primary education. A similar pattern prevailed in high-achiever developing countries as well, where primary education became universal early in their development process when incomes were still low.

This policy of state support in the so-called high achievers was not restricted to basic education but extended to all basic social services; in other words, these states did not rely upon a trickle-down of the benefits of growth or a policy of 'unaimed opulence' (to borrow a term from Sen and Dreze, 1989). These countries, belonging to opposite ends of the political-economic spectrum in terms of macro-economic policies, made early public investments in basic social services when incomes were still low (Mehrotra and Jolly, 1997). ${ }^{10}$ In other words, they anchored their education policy on social integration, equality and lower unit costs through state provision, as explained in section 2 (especially Table 1).

The recent thrust in favour of multiple providers in the area of social provisioning (deriving partly from new institutional economics) ${ }^{11}$ has tended to ignore the historical experience of industrialized countries in the 19th century, as well as the more recent experience of the high-achievers among developing countries. It has relied rather on other kinds of arguments to press the case for a greater role for private providers in education.

A first argument for private expansion made since the mid-1980s, relies on the scarcity of public funds. As budget deficits got out of hand in many African and Latin American countries in the 1980s, the IFIs in particular started making the case for private sector expansion in the school system. However, given the fiscal squeeze on government education budget, the balance between elementary and secondary education in public expenditure allocation will have to respond to prevailing conditions. If primary schooling has not been universalized (e.g. India), then allocating a high share of public spending to secondary education may be inefficient and inequitable. But as primary education gets universalized, the balance of public education spending is bound to - and in fact must - shift in favour of the secondary level. A study by the United Nations Educational, Scientific and Cultural Organization (UNESCO) Institute of Statistics/OECD of 16 developing countries shows that the countries with the highest share of private upper secondary enrolment are also those with the lowest overall enrolment rates (India, Indonesia, Zimbabwe). But in China, Malaysia, Jamaica, Thailand - all with relatively total high secondary enrolment rates - more than $90 \%$ of direct expenditure on education reaches the public schools.

At the same time, a resource-constrained state cannot subsidize elementary education (i.e. grades 1-8) in the private sector, while the public sector is starved of funds. However, as Mehrotra et al. (2005) point out, that is exactly what is happening in India. In India, the private-aided (i.e. managed privately but receiving significant government funding) schools' share in enrolment 
tends to rise with the level of education: it is lowest at the primary level, rises sharply at the upper primary level, and is the highest at the secondary/higher secondary level. In fact, more than half of children at secondary/higher secondary level are in private (aided and un-aided) schools. This kind of subsidy to private schools tends to squeeze the funds available for public elementary schools.

A second argument for greater private provision in schooling is based on the better cognitive achievement (as manifested in language and math tests) of children in private schools compared with that of those in public schools, as indicated in several country studies. A number of papers emerged, largely from the World Bank, reporting a significant private school advantage in terms of cognitive achievement. Cox and Jimenez (1991), Jimenez, Lockheed, Luna et al. (1991) and Jimenez, Lockheed and Paqueo (1991) studied Colombia, the Dominican Republic, the Philippines, Tanzania and Thailand, and found that the private school advantage (on math scores) is in the range of $13 \%$ in Colombia to $47 \%$ in the Dominican Republic. In the same countries, Jimenez and Lockheed (1995) found that per pupil cost is lower in private schools. In any case this argument has been subjected to some methodological criticism and is not conclusive.

Bashir (1997) notes that these studies using single-level models seemed to show that private schools were more effective. These models tell us more about the possible variables that influence cognitive test achievement than the private-public comparison. There is such a variety in the possible variables influencing achievement that different studies come up with (including the ones cited), and yet very few variables that can be called 'school policy' variables have been shown to explain the variation in school outcomes. Colclough (1997) provides similar conclusions.

Thus the case for multiple providers, although it cannot be easily brushed aside, loses much of its force from empirical realities. ${ }^{12}$ Besides, the studies cited more often than not relate to the secondary level of education. In any case, the private sector is likely to grow regardless of whether the government subsidizes it or not, as incomes grow. Therefore, at all levels - elementary, secondary and tertiary - there is a need for much better regulation of the private sector.

Under what circumstances can the private sector's role in education be complementary to that of the public sector? Despite its potential drawbacks, public funding of private schools can help in certain circumstances - particularly if governments have trouble, on account of fiscal constraints, meeting the full costs (building schools, paying teacher salaries) required to achieve universal primary schooling. To ensure that children from poor families unable to pay school fees are able to attend private schools, governments could finance their education through subsidies. Colombia, for example, introduced a voucher system in response to a shortage of public secondary schools. This approach to public funding of private education can help expand 
schooling at lower cost for the government, because the only cost the government bears is the subsidy to the low-income family. This is very different from a voucher system that enables families to enrol their children in the school of choice, public or private. To avoid giving windfall gains to the middle class that customarily purchase private education, subsidy should be restricted to poor families - as in Bangladesh, Chile, Colombia, Puerto Rico and the UK (Kremer, 2003). Thus, in this manner there is scope for promoting complementarity between the public and private sectors.

Moreover, there is no question that there is a case for growth of private supply of secondary school and tertiary school places (within the boundaries described in section 2); thus complementarity between the private and public sectors can be encouraged by letting the private sector concentrate on higher secondary and tertiary education, and if public resources are scarce, the public sector could focus on the primary and junior secondary levels. This is the path adopted by one of the early high-achievers, South Korea (Mason et al., 1980). Of course, this does not imply that free, public universities should be avoided. On the contrary, they play a fundamental role in expanding opportunities for poorer and lower middle-income households to see their children improve their chances for obtaining better jobs in dynamic occupations. The balance needs to be struck in a way that public universities can be financed without short-changing elementary education because in that case, the poorest children cannot arrive at the secondary schooling they need to proceed to the university and only the richest families enjoy the colleges and universities.

\section{Health}

Around the world, clinical services are financed in four ways. Two are private - direct payment and voluntary private insurance - and two are public compulsory (social) insurance, which is managed or regulated by government, and financing from general government revenues. Despite the existence in most countries of the four forms of financing health services, private and social insurance are more widely applicable in economies with a large formal sector. In most low-income countries, for the poor, who are usually in the rural areas, or in informal sector activities in the urban areas, the realistic options are public finance and public providers, or some form of community pooling of household resources to meet the costs of public/private provision, or out-of-pocket payment to private providers. Knowing that out-of-pocket payments are neither fair to the poor, nor efficient - given the externalities involved in 'good' health - public provision or community-level pooling are two options that should be widely applicable in all developing countries. Reasons of space will prevent us from discussing public provision or community-level pooling (see for a detailed discussion Mehrotra and Delamonica, forthcoming; World Bank, 2003; World Health Organization 
[WHO], 2000). However, the near-marketization of public provision and social insurance in some developing and transition economies will be discussed.

In addition to the four forms of financing, there are three ways of delivering clinical services: private for profit, private not-for-profit (e.g. missionary hospitals) and public. It is with the first form of delivery that we are mainly concerned in this section.

As in the education sector, the World Bank has been encouraging welfare pluralism, especially in the delivery of health services. This is despite the historical evidence that the role of the public sector in the latter half of the 19th and early 20th century in Europe in both clinical services as well as areas of public health was predominant, notwithstanding the welfare pluralism. In fact, to date, in northern and southern Europe government finance provides access to health services for the majority of the population. In Switzerland and the USA it is mainly private insurance, and in Germany and the Netherlands social insurance prevails (Normand, 1997).

The experience from the high-achieving developing countries, which managed to improve their health indicators early in their development process relative to other countries in their region, is not dissimilar. They provided universally available health services to all, paid out of government revenues. In many of those countries the relatively well-off opted out by taking private health insurance (e.g. South Korea, Costa Rica), or where private insurance services were not available (e.g. Sri Lanka, Kerala) by making direct payment to private providers. But for the vast majority of the population a universally available and affordable system, financed out of government revenues, functional at the lowest level, made effective by allocating resources at the lower end of the health system pyramid - these were the keys to high health status (Mehrotra, 1997).

Nevertheless, since the mid-1980s many countries that had very limited or entirely banned for-profit practice (e.g. Malawi, Tanzania and Mozambique) have been encouraging private providers by regulatory liberalization and fiscal incentives (not necessarily privatization of public hospitals). Besides, many low- and middle-income countries already have a substantial and thriving private sector - in Latin America, South Asia, South-east Asia, and to a much lesser degree in Sub-Saharan Africa. Correspondingly, a very significant proportion of health expenditure in all regions is private. Not surprisingly, South Asia and Sub-Saharan Africa have among the worst health indicators of any developing region of the world.

More than any other regions, Latin America has experienced in the 1990s an unprecedented transnationalization of its health sector - with what results is worth examining (as we do later). There has been an increase in the export of managed care from the USA, and its adoption in Latin America. Several multinational corporations (e.g. Aetna, CIGNA, AIG and Prudential) have entered insurance and health services, and they intend to assume adminis- 
trative responsibilities for state institutions and to secure access to medical social security funds. About $270 \mathrm{~m}$ people in Latin America, $60 \%$ of the population, receive cash benefits and health care services paid for by, and often delivered by the employees of, social security funds. The three main ways that these corporations invest in Latin American health systems are through: (1) the purchase of already established companies in Latin America that are dedicated to the sale of indemnity insurance or of prepaid health plans; (2) association with other companies under the framework of a joint venture; and/or, (3) agreements to manage social security and public sector institutions. Penetration by multinational corporations in health of these social security funds is most advanced in Argentina and Chile, has begun in Brazil and is growing, and is in the process of diffusion in Ecuador (Iriart et al., 2001).

One reason this transnationalization of the health sector has occurred is because it has been encouraged by the IFIs. World Bank advocacy for the private sector began with its 1987 publication, Financing Health Services in Developing Countries, which proposed four steps: (1) increase the amount patients pay for their own health care, (2) develop private health insurance mechanisms, (3) expand the participation of the private sector in health care, and (4) decentralize governmental health care services (World Bank, 1987). However, while a strategy of this kind ensures that government spending is focused on the most cost-effective interventions, it might still fail to ensure that the sector as a whole will operate in the most efficient manner, given the state's inability and often its unwillingness to perform appropriate regulatory functions. Later the Bank advocated public sector financing, and possibly provision, for a package of basic preventive and curative services, while more complex services are left to the private sector (as argued in World Bank, 1993).

The 1993 World Development Report (on health) states:

In most circumstances ... the primary objective of public policy should be to promote competition among providers - including the public and private sectors ... Competition should increase consumer choice and satisfaction and drive down costs by increasing efficiency. Government supply in a competitive setting may improve quality or control costs, but non-competitive public provision of health services is likely to be inefficient or of low quality. (World Bank, 1993)

Where appropriate sectoral policies are adopted (e.g. as in the highachiever countries) problems of quality and efficiency in the public provision of basic services has not proven insuperable. There are plenty of examples of 'highly efficient public health centres and district hospitals' (World Bank, 1993). ${ }^{13}$ Indeed, there is also increasing evidence that efficiency and effectiveness is closely tied to governance issues, and deep democratic decentralization has successfully addressed those problems in many locations. What evidence there is in respect of the claims the neoliberals make on behalf of the private sector in health, we examine briefly here. 
The evidence on the standards of efficiency and quality in the private sector relative to the public sector is inconclusive (Bennett, 1997; Mills, 1997). First of all, the evidence is that there is very significant market segmentation between public and private sectors that makes it necessary that case-mix and severity of disease is the same across services before they can be compared. ${ }^{14}$ If the public sector is treating rather different types of cases from the private sector, comparisons will be invalidated. Evidence is lacking in developing countries that make these kinds of controls.

Second, there is plenty of evidence of market failure where health services are largely in the private sector. A significant proportion of the hospitals and health facilities are in the hands of the private sector in Asia, Latin America, and increasingly in Africa as well, though preventive measures are largely the responsibility of the public sector (Berman and Rose, 1996). Bennett and Tangcharoensathien (1994) found that in India, South Africa, Thailand and Zimbabwe private sector providers rely on relatively untrained staff with limited supervision from physicians. Studies also point out that over-servicing is a major problem in the private sector. In Brazil there was a high rate of caesarean sections in private maternity patients, explained by the financial pay-off for providers for operating rather than permitting a normal delivery (Barros et al., 1986). Similarly, Uplekar (1989, cited in Bennett, 1997) found that in a slum area of Mumbai drug prescriptions did not match WHO recommended practices, and a larger number of more costly items was prescribed.

Third, there is increasing evidence in many countries where private provision is extensive, both low- and middle-income, of rising costs and accumulation of technology. In 1993 drugs accounted for 52\% of China's health spending, compared with $15-40 \%$ in most developing countries contributing to unnecessarily high medical costs. In Korea and Thailand the availability of certain high technology equipment is the same or greater than that in most European countries, even though the level of per capita income is much lower (Nittayaramphong and Tangcharoensathien, 1994; Yang, 1993). Where in Latin America managed care organizations have taken over the administration of public institutions, increased administrative costs have diverted funds from clinical services. To attract patients with private insurance and social security plans, Buenos Aires public hospitals hired management firms that receive a fixed percentage of billings, increasing administrative costs. Administrative and promotional costs account for 19\% of Chilean managed care (ISAPRE) annual expenditures (Iriart et al., 2001). ${ }^{15}$

Fourth, it is often claimed that an expanding private sector will reduce pressure on an overextended public sector, thereby freeing up capacity and resources in the system as a whole. The International Finance Corporation (IFC; the arm of the World Bank group promoting private sector investment in developing countries), outlining its future strategic priorities, considered education and health as targets for the promotion of the private sector on 
precisely these grounds (IFC, 2002a). In fact, the IFC established a separate Health and Education Department in September 2001 (IFC, 2002b). However, as Bennett (1997) argues, there are no longitudinal studies examining changes in total funding levels in response to increased private sector funding. In fact, the IFC itself admits as such: 'By producing extra capacity in the sector as a whole, the public sector will be able to redirect its scarce resources to those most in need . . . However, it [this argument] is undermined by a lack of any real evidence.' If anything, private sector growth may lead to a withdrawal of inputs from the public to the private sector. Thus the growth of the private sector in Thailand in the 1980s and 1990s saw a drain of personnel away from an already stretched public sector.

Finally, the effect of privatization of health services and the reliance on outof-pocket financing is to worsen equity in health care (see section 2). The most serious effect is that services are refused on account of inability to pay and illness goes untreated. Thus, the concerns about managed care in Latin America are about restricted access for vulnerable groups, and reduced spending for clinical services as opposed to administration and return to investors. In Chile, about $24 \%$ of patients covered under the new managed care organizations receive services annually in public clinics and hospitals because they cannot afford co-payments (required under the managed care programme). Public hospitals in Argentina that have not yet converted to managed care principles are facing an influx of patients covered by privatized social security funds. Self-management in Brazil and Argentina's public hospitals requires competition for capitation payments from social security funds and private insurance, as well as co-payments. To apply for free care at public institutions, poor patients now must undergo lengthy means testing, with rejection rates averaging $30-40 \%$ in some hospitals (Iriart et al., 2001). Meanwhile, those public hospitals in Argentina that have not yet converted to managed care principles face an influx of patients covered by privatized social security funds; they had earlier faced barriers to access due to co-payments and private practitioners' refusal to see them because of non-payment by the social security fund. Also, Latin American managed care organizations have also attracted healthier patients while sicker patients shift to the public sector - undercutting the very notion of pooling of health risk and undermining any possibility of cross-subsidy from the healthier to the more vulnerable.

The results for health equity of privatization of health services and private sector growth in health care are not dissimilar in the transition economies as in other developing countries. Thus, the impact of the transition to a 'socialist market economy' in China has been that the cost of health care increased rapidly due to health worker salary increases, growth in drug spending, and an increasing use of expensive technology (at least in richer areas). Meanwhile, government spending on health trailed behind the salary increases, and the public health services started deriving an increasing share of their budgets from sale of drugs and user fees (Bloom, 1997). In household surveys in rural 
China, 35-40\% of people who reported that they had an illness did not seek health care for financial reasons (Hao et al., 1997). In the Kyrgyz Republic, more than half the patients referred to hospital were not admitted, as they could not afford hospital costs. In Vietnam, the average cost of hospital admission is the same as two months' wages, resulting in loans and debts. Thus, in rural north Vietnam, $60 \%$ of poor households were in debt, with a third citing payment for health care as the main reason (Whitehead et al., 2001).

An increase in private medical practice and a huge growth in private pharmacies in developing countries is a further source of inequity in health. This arises from the irrational use of drugs, which raise costs and leads to drug resistance. In developing countries, drugs now account for $30-50 \%$ of total health care expenditure, while in industrialized countries it accounts for only 15\% (Velasquez et al., 1998). Those who cannot afford professional services are essentially catered for by pharmacies, which often do not follow prescribing regulations. This is especially the case in South Asia, China and parts of Africa. In India, 52\% of out-of-pocket health expenditure and $71 \%$ of in-patient expenditure goes to medicines and fees (Iyer and Sen, 2000). Pharmacies have a financial incentive to over-prescribe and sell drugs, which leads to unnecessary drug use, and the development of resistance to drugs. Vietnam has a high frequency of antibiotic resistance resulting from irrational drug consumption; two-thirds of those who reported illness in the previous four weeks had obtained medicines without consulting a medical practitioner (Tornqvist et al., 2000). In a poor region of Mexico, three-quarters of health care visits led to inadequate treatment, particularly from traditional healers or drug retailers. If poor patients have overspent on unnecessary drugs, they may not be able to continue a regimen of drugs (e.g. for malaria or tuberculosis). Then the ingestion of these drugs would become infructuous, and the drug resistance can threaten a whole community. In the developing world there is widespread over-prescription of antibiotics for cases of diarrhoea. In six Latin American countries a quarter of drugs bought from pharmacies required a prescription (as they needed medical follow-up), but were sold without one (Whitehead et al., 2001).

This evidence suggests that there is great need for regulation of the private sector in health services (as in education), for reasons of protecting consumers as well as containing costs. However, in most developing countries the government's health ministry normally has an extremely weak information system about the private sector (or for that matter about the public sector), underlining their inability (or unwillingness perhaps) to regulate the private sector. Bennett (1997) cites widespread regulatory failure in India in respect of the private sector, with the medical councils 'concerned more with protecting those whom they are supposed to be regulating than with protecting consumers. This problem is well recognized in the literature.' In fact, despite the widespread presence of private providers in South Asia, and 
the high level of private spending, regulation has failed abysmally in ensuring quality for the majority who access private providers (Rohde and Viswanathan, 1995).

\section{CASE STUDY: INDIA}

Many of these issues are well illustrated in the case of India. More than twothirds of health expenditure in India is incurred in the private sector; this is hardly surprising given that four different studies have demonstrated that the private practitioner is the mainstay of rural medical care, consulted first (and exclusively in most cases) for $60-80 \%$ of illness (Rohde and Viswanathan, 1995). The health system in India is, for all practical purposes, privatized, and the results (except in parts of the country like Kerala) evident in the high child and maternal mortality and the life expectancy of 60.7 years. There are consequences for equity. Deolalikar and Vashishta (1992) found that for three income classes in India, the poorest (below an annual income of Rs12,500) spent $24 \%$ of income on health, while the richest spent $3.4 \%$, and those in the middle $7.6 \%$.

After independence from British rule in 1947, the government decided to abolish a course of study in modern medicine leading to a diploma in medical practice. These licentiates were meant to serve rural areas (Ramalingaswami, 1995). But the policy makers felt they were not good enough and decided that a university degree with over five years of study after 12 years of school should be the minimum professional qualification to practice medicine in India. But these physicians with five years of medical training were unwilling to locate in rural areas. The result has been that despite a vast public health infrastructure, issues of access and equity are extremely serious. In rural India (as in much of rural South Asia), the first port of call of the sick is not a trained physician, but the uncategorized rural private practitioner, most often unlicensed, and not formally trained. As Ramalingaswami describes them:

Even those formally trained in the indigenous systems prefer using allopathic medicines. They dispense, rather than prescribe, they are more approachable and responsive than the average government doctor, indulge in detailed conversation with patients in a culturally comforting manner, not lifesavers but alleviators of symptoms. The government health system, on the other hand, is surrounded by problems of physical distance, long waiting times, cursory examinations, no encouragement of dialogue, doctors often unavailable, counting the number of days to return to the urban centre. (Ramalingaswami, 1995: vi).

This rural private practitioner is helped by the existence of a very large pharmaceuticals industry and the presence of pharmacies at every corner. India is a leader in the world of drug production with 65,000 licensed products and over 16,000 pharmaceutical manufacturers licensed in the country. This can be contrasted with only $10 \%$ of that number of drugs in a typical country in Europe and North America. The choice of drugs by the rural private 
practitioners is made largely through interaction with commercial pharmacies in neighbouring towns.

Both the practitioners themselves and their patients consider their practice limited to minor illnesses and their treatment is related to rapid relief from symptoms rather than total cure of the disease. In other words, they are functioning as primary health care assistants, who refer the more serious problems to other professionals usually located in towns and cities.

This situation is remediable. This vast army of unlicensed practitioners can be co-opted in a partnership with the state. A non-goverventmental organization (NGO) of professional licensed providers, with government support, should take on the role of identifying, communicating with and improving the practice of rural practitioners. This would reverse the current situation that neither the government nor formally licensed practitioners are willing to recognize them and improve rural practice. Such an NGO could become selffinancing through fees generated from membership. Equity is not usually associated with these practitioners, but the widespread distribution of such practitioners, their accessibility to the poor, and their willingness to extend credit to provide services or payment in kind makes an equitable outcome possible even in the private sector.

If the practitioner is a member of this organization that is symbolic of medical quality, it will help increase the demand among practitioners for participation in training. It will help the public recognize that the provider is linked to a higher referral system. It would assure more timely referral of patients to the level of technology they require, but also reduce overload on secondary and tertiary facilities (which are often providing primary health care to many health seekers currently).

\section{Water and Sanitation}

The water and sanitation sector is quite unique among the sectors discussed in this article. The proportion of the population of the world still lacking safe water and sanitary means of excreta disposal by far exceeds those lacking health or education services. There is little doubt that government provision of the 'merit good' of water, sanitation and public health has not been achieved in low- and middle-income countries. In the 1990s there has been a significant increase in the provision of urban water services in developing countries by the private sector. ${ }^{16}$

This section begins with a review of the growth of private-public partnerships (PPP) internationally, goes on to examine some specific cases of PPP in low- and middle-income countries, and concludes with the possible way forward. ${ }^{17}$ The focus of this analysis is, by definition, on ensuring services to the poor and to those without services - rather than with promoting any particular form of ownership or management of the water and sanitation 
sector. This must take into account the fact that the vast majority of the poor in low-income countries live in rural areas. In middle-income countries, however, the majority of the population lives in urban areas (e.g. Latin America and the Caribbean, Central/East Europe and the Commonwealth of Independent States).

It is remarkable that of the 715 reported PPPs since 1989 by region in water and sanitation, $60 \%$ are located in the most urbanized parts of the world Western Europe (16\%), North America (12\%), Central/East Europe/CIS $(6 \%)$, and most significantly Latin America and the Caribbean (26\%) (Franceys, 2001).

However, this is not to suggest that PPPs have not grown in the rest of the world. In fact, the distribution of the remaining $40 \%$ of PPPs in the world is as follows: East Asia and the Pacific 16\% (39\% population urbanized), South Asia 10\% (29\%), Sub-Saharan Africa 10\% (38\%), and Middle East and North Africa 4\% (62\%). This is despite the fact that a much smaller proportion of the population is urbanized. In any case, world-wide, the present population reported served by PPPs in middle- and low-income countries probably represents less than $5 \%$ of the total urban population in these countries. In fact, in the 433 cities with a population larger than 750,000, 90 cities (or 20\%) are currently served by PPPs (Franceys, 2001); however, there are around 40,000 smaller cities and towns. ${ }^{18}$ The main concern, hence, remains the estimated $25 \%$ of the citizens of developing country cities that use water vendors purchasing water at significantly higher prices than piped water (Water and Environmental Health at London and Loughborough [WELL], 1999). The result of this growth in PPPs in water and sanitation in the 1990s has been that many governments now accept that the private sector can share a greater responsibility for the water and sanitation sector than before, and the approach is somewhat different from that for other utility monopolies, electricity and gas. Since there also seems to be increasing consensus among international donors (especially the World Bank and the IFC) to promote PPPs in urban and peri-urban areas, it is necessary to look at the experience of PPPs in both industrialized and developing countries.

Meanwhile, there is much greater agreement that rural areas will be served through user committees with NGO support. Governments need to focus on promotion, facilitation and coordination of services rather than merely on their provision. In the rural areas in particular, sustained service provision would be best achieved through the efforts of local communities and locally based public and private firms, and building this capacity is recognized as an important role for governments. At the same time, the private sector already plays a role in service delivery in the water and sanitation sectors to the poor. At the community level, artisans often construct and maintain water and sanitation systems, performing an important marketing role as well, especially in sanitation. Private sector involvement is increasing in the design and manufacture of hardware (e.g. pumps, pipes and sanitary wares), in the 
implementation of schemes (e.g. design and drilling of boreholes), in the delivery of services (e.g. private utilities and cooperatives) and in operation and maintenance (e.g. the increasing number of hand-pump repairers) (UNICEF, 1995; see also Trawick, 2003).

Given the growing role of PPPs in the urban areas, what has been the experience with them? PPP contracts in the water and sanitation sector with increasing degrees of private participation, start from cooperatives, moving on to service contracts, management contracts, lease contracts, BOT (Build, Operate, Transfer) contracts and their variations, concession contracts, and finally divestiture implying full private ownership under a regulatory regime. ${ }^{19}$ The last has mainly happened in industrialized countries (e.g. England and Wales, though not in Scotland and Northern Ireland) while the rest have been implemented in a variety of low- and middle-income countries. In France, the government owns the fixed assets and one of the three major private companies takes full responsibility to operate the systems, as in a lease contract. In the industrialized countries there is strong evidence that with PPP the prices have increased significantly, e.g. in France prices are higher in communes with PPP than those without, but there is no information as to what extent standards are correspondingly higher (Franceys, 2001). It is the French pattern that is now being promoted around the world, though the process was started in the UK in early 1980s (where private company profits have been high). ${ }^{20}$

Services contracts and management contracts together account for $45 \%$ of all PPP contracts by number (in operation until November 2000) in low- and middle-income countries. BOT accounts for another $23 \%$, and concession contracts for $18 \%$. The latter tend to be more complex contracts, while services contracts could be seen as an opportunity for developing country governments to build up expertise in the sector before taking on the more demanding role of managing a concession. ${ }^{21}$ Thus the more complex PPPs are mainly found in middle-income countries in regions such as Latin America, East Europe and South-east Asia. Among the low-income countries, only francophone West Africa has an established record in complex PPP - one reason for which may well be that the international companies most globally active are French ones. Initiatives are being pursued actively in Southern and Eastern African and also South Asia, with support from donors (Webster and Sansom, 1999).

By and large, so far, the term PPP in the water and sanitation sector really implies involvement with a foreign partner. Seventy percent of the operating PPPs requiring capital expenditure involve international contractors. Twothirds of those contractors originate from France - the country with the longest domestic history of PPP (over 100 years). Contractors' share of lowand middle-income country market by reported capital expenditure shows that the French Lyonnaise des Eaux $(50 \%)^{22}$ and Vivendi Water $(17 \%)^{23}$ have two-thirds of the market. By number of reported PPPs the same two companies have $55 \%$ share in the overall international market; the British 
companies have a quarter share but they have focused on safer markets in Europe and North America. ${ }^{24}$ The fact of foreign involvement indicates that privatization also involves about $1 \%$ (by staff numbers) of expensive expatriates (US\$250,000 per annum) to deliver a so-called 'world class' water supply. As Franceys (2001) notes, this clearly puts a limit to the size of the city that can be served by a foreign PPP.

Evidence on whether the PPPs that have grown from almost nil at the beginning of the 1990s to over 2350 have been effective is mixed. One of the main claims for privatization was that it delivers the required new capital to the sector; that is the reason why PPPs are being discussed under the heading of mobilizing additional resources for basic services. It is unclear whether any significant new money is coming into the water and sanitation sector, as most PPPs have only a small equity contribution. At the same time, PPP is based on the assumption that in the end the customer pays. PPP has made this fact more obvious though that is not always government intention.

\section{SOURCES OF CONFLICT IN PPPS}

There remain a number of sources of tension between the public and private partner in PPPs, some of which will become clearer in the specific cases in Latin America (e.g. Bolivia, Chile) and Africa (e.g. South Africa) that are discussed. First, there is usually a sharp difference between what private companies see as the minimal return necessary to sign a contract in a risky country and what governments view as an acceptable level of profit (Cowen and Penelope, 1997).

Second, management contracts can be good at improving services for those who already have water connections, but typically do not help those without connections, who are also less politically influential.

Third, given the few international companies in the business, as we saw above, competition is limited to begin with. The company winning the management contract for a limited period will start with an advantage for later contracts, and in the light of this fact, other bidders may not be attracted. Thus, in either case, competition is likely to be limited or absent during the shift to a more complex contract. In other words, despite all the theoretical arguments marshalled by new institutional economics in favour of competition, privatization need not necessarily result in competition, not even in the bidding process.

Fourth, countries have limited regulatory and administrative capacity to manage such contracts. The political importance of the sector makes bidders nervous about whether governments will maintain a favourable operating environment and tariff yielding a reasonable rate of return. Management contracts in turn require clear performance indicators and a monitoring agency with the skills, budget and autonomy to perform the task. However, many of the normal indicators of water utilities' performance may only partially be controlled by the private management contractor. For example, as 
Cowen and Penelope (1997) rightly note, water loss reduction in physical terms may depend upon government investing in rehabilitating pipes. Improved revenue collections may depend upon government users paying their own bills and state support for a policy of disconnection for nonpayment. Reduction in operating cost may depend on laying off workers.

Fifth, an initial contract in a PPP is often based on quite incomplete information about many factors, e.g. the condition of underground assets, or future investment requirements. Hence provision must be made in contracts to deal with unforeseen events over the life of a contract. International arbitration is often suggested in countries with little history of judicial or regulatory independence. Yet such arbitration is expensive, and for most disputes and for many smaller contracts it may not be realistic.

\section{CASE STUDIES OF PPPS}

Many of these issues have arisen in two cases that are discussed here. Since 1984 the Bolivian government has been hailed by the IFIs as an 'early adjuster', and like Argentina had carefully followed the neoliberal policy package. However, as in much of Latin America, poverty had not declined. In 1999 the Bolivian government conducted an auction of the water system of the old Andean city of Cochacamba (Finnegan, 2002). The auction drew only one bidder: a consortium called Aguas del Tunari, the controlling partner in which was International Water, a British engineering firm then wholly owned by the Bechtel Corporation of USA. The government, regardless of its weak bargaining position, still proceeded. The terms of the US $\$ 2.5 \mathrm{bn}, 40$-year contract reflected the lack of competition for the contract. Aguas would take over the municipal water network and all the smaller systems - industrial, agricultural and residential - in the metropolitan area, and would have exclusive rights to all the water in the district, even in the aquifer. The contract guaranteed the company a minimum $15 \%$ annual return on its investment, which would be adjusted annually to the consumer price index in the USA. ${ }^{25}$ On cooperative wells Aguas could install meters and begin charging for water. Residents would also be charged for the installation of meters. These expropriations were legal under a new water law that had been rushed through the Bolivian parliament.

The terms of the contract for water privatization were immediately questioned by engineers, environmentalists, a federation of peasant farmers who rely on irrigation, neighbourhood associations and water cooperatives. In January 2000 surprised business owners and middle-class householders joined the protest, as some bills had doubled, and ordinary workers had water bills that amounted to a quarter of their monthly income. The response of Aguas was simply that if people did not pay their water bills their water would be turned off.

The consortium had agreed in its contract to expand the city's water system, which was going to require large-scale repairs of the deteriorating existing 
system. The company claimed that they had to reflect in the tariff increase all the increases that had never been implemented before. The consortium had also agreed to finish a stalled dam project, Misicuni, which would pipe water through the mountains. Although plans for the dam had been around for decades, World Bank studies had pronounced Misicuni as uneconomic; nevertheless, the dam was included in the contract with Aguas. ${ }^{26}$

The conflict sharpened, protests mounted, the government sent in troops from La Paz. In April 2000 the national government declared a national state of siege or martial law and it allowed mass arrests. The company's executives were told that the police could no longer guarantee their safety and they departed. The Mayor distanced himself from the company. The government informed the company that because the company had abandoned its concession, its contract was revoked. A new national water law was passed, 'written from below' as water-rights campaigners say. The management of Cochacamba's water system was returned to the old public utility (SEMAPA). In late 2001 the consortium filed a complaint against the Bolivian government. The claim is being made under a bilateral investment treaty between Bolivia and the Netherlands (after Bechtel moved its registration to Amsterdam). Bechtel and its partners are demanding at least US\$25m in compensation for the broken contract.

One can see here several of the latent sources of conflict we mentioned earlier between the three parties involved: the people, the government and the company. There was hardly any competition during the bidding stage, and the company obtained terms that were part of the problem. Second, tariffs had presumably been low in the years in the run up to privatization, and the company's attempts to raise tariffs suddenly, rather than in a gradual manner, brought on massive protests, worsened by attempts to cut off water to those unable to pay. Third, the local and national government could have acted in a more participatory manner, consulting with the affected people, before taking decisions - but did not, with serious consequences. Fourth, the dispute has finally gone to arbitration abroad, rather than within Bolivia, which could prove rather expensive for the government.

As in Bolivia, water privatizations have caused large-scale protests in many parts of Latin America. Thus, in Panama popular discontent about an attempted privatization cost the President his bid for re-election. Vivendi, the French water transnational, had its 30-year water contract with the Argentine province of Tucuman terminated after two years because of alleged poor performance. There was a $100 \%$ increase in water rates after Vivendi was granted a 30-year concession to supply Tucuman province. Major water privatizations in Lima (Peru) and Rio de Janeiro (Brazil) have had to be cancelled because of popular opposition. Trinidad recently allowed a management contract with a British water company to expire. Protests against water privatization have also occurred in Indonesia, Pakistan, India, Poland, Hungary and South Africa (Finnegan, 2002). 
It is not that there have not been some successes with the privatization of water services. ${ }^{27}$ However, the most exhaustive review of the international literature lists the following likely problems with PPPs: 'corruption in the tendering and drawing up of contracts, particularly in the US; monopoly in the privatized service; higher user charges; inflated director's fees, share options, and management salaries; widespread retrenchments; and anti-union policies' (Hemson, 1997, cited in WELL, 1999).

In fact, the international water companies are themselves recognizing the risks and pulling back. ${ }^{28}$ Thames Water had run its Shanghai sewerage plant for four years before China's government ruled in 2002 that the agreed rate of return was illegally high. Thames pulled out in July 2004. Despite this pull out, China is the only country where the international water majors are staying. Veolia added a contract in December 2003 to seven already there.

A major reason for the majors pulling out is that in most contracts the rate of return is guaranteed in foreign currency, but the national currency often undergoes devaluation. In Jakarta, in Manila, in Argentina, in country after country where water services were privatized, there has been devaluation. The companies are happy enough while the national currency is stable, but when, for example, the Argentine peso (long tied to the dollar) collapsed in 2002, troubles started. Suez's debt was mainly in dollars, but its charges to consumers were in pesos, and it was denied permission to raise them accordingly. Unlike the currency of other developing countries where the majors have invested, China's is, if anything, likely to rise - and so in China the water majors are staying for now.

\section{THE WAY FORWARD}

In face of this growing evidence of dissatisfaction with PPPs in the water and sanitation sector, what is the way forward? The structures of the public sector currently provide water services to around $95 \%$ of bulk water distribution customers globally. Many are indeed over-sized, inefficient, over-staffed and bureaucratic - as normally depicted by the proponents of privatization. Many, however, are organizations that have been delivering reasonable public service, taking environmental and financial sustainability into account.

Thus, Chile successfully universalized access to safe water for its urban population by 1990 - and unlike most other countries in the region, the reforms did not involve the decentralization of the responsibility of the service to other levels of government, such as municipalities, or the direct privatization of the service (Lee, 2002). Traditionally, water and sanitation services in Chile were provided by a variety of central and local government authorities. The large number of organizations, their lack of financial and administrative autonomy, the lack of strategic planning and coordination failures resulted in a poorly operating water and sanitation sector. Reforms began in 1977 with legislation that led to the creation of a centralized service, responsible for water and sanitation in urban and rural areas in all of Chile. 
The National Sanitation Works Service (SENDOS) was created within the Ministry of Public Works, to plan, control and regulate. For operational purposes 11 regional agencies were established to cover the country. Thus one crucial aspect of the reform was the separation of the responsibility for the regulation of provision from the responsibility to operate the service.

Second, there was an increase in investment in water and sanitation. In the 15 years prior to International Water Supply and Sanitation Decade, 198190, investment averaged US\$62 m, but between 1981 and 1990 it averaged US $\$ 105 \mathrm{~m}$ at 1995 prices. The proportion of population receiving service also increased dramatically to $97 \%$ of the urban population enjoying a household connection to water supply and over $80 \%$ a connection to a sewerage system. The provision of services to the concentrated rural population was also resolved.

Third, private contractors were also involved for some service contracts. However, $41.5 \%$ of the population was served by the 11 state-owned regional companies, $50 \%$ (in Santiago and Valparaiso) by two other state-owned ones, $4 \%$ by a municipal company, and only $3.9 \%$ by six private companies.

Fourth, between 1988 and 1990 there was established a new system for fixing tariffs objectively. The regulator established a maximum tariff on the basis of a model efficient provider and any differences of opinion between the actual company holding the concession and the regulator were to be resolved by a tripartite commission of experts. The reform permitted the gradual adjustment of the existing tariffs to the new, higher levels (Lee, 2002).

Although dominated by public enterprises Chile's water services have been very successful. There were incentives for efficiency: the public enterprises wish to prove that they can be effective and profitable, and the private operators, although small, provide a benchmark for comparison. There was a sharp increase in the contracting out of many operational activities by all companies, including operation, management and capital investment of whole systems, as well as maintenance of all aspects of the networks, meter reading and billing. Contracting out reduced the number of workers per connection. In 1995 the average level of unaccounted for water in the water utilities was 30.6\%, far less than the Latin American norm of 40-60\%. There was also an increase in investment, the majority of which comes from operating income, itself made possible by the tariff increases, and the rest from various governmental funds.

Chile is not the only country where water and sanitation services have been delivered efficiently by predominantly public enterprises. In fact, a report by the Public Services International Research Unit (PSIRU) lists case studies of successful public water providers, some of which have fended off attempts at privatization. 'Contrary to common assumptions, there is ample evidence of satisfactory achievement of social and public service objectives through efficient public sector undertakings, in transition and developing countries as well as developed ones' (Lobina and Hall, 1999: 10). ${ }^{29}$ 


\section{The Private Sector: Full Speed Ahead?}

We noted in section 1 that there has been international pressure for PPPs and privatization in social services. In fact, recent developments in multilateral bodies - the World Bank, the IFC, World Trade Organization (WTO) - as well as bilateral policies are likely to force the pace of privatization and private sector development in health, education and water, and sanitation now. We discuss in turn the World Bank-IMF's Poverty Reduction Strategy Papers, the World Bank's new Private Sector Development Strategy, the IFC's new strategic priorities, the interest of WTO and finally, regional treaties and their links with the privatization process.

Since 1999 the World Bank and IMF have required all Heavily Indebted Poor Countries (HIPCs) and all countries applying to the Poverty Reduction and Growth Facility (PRGF; or the erstwhile Extended Structural Adjustment Facility [ESAF]) - or concessional lending facility - to prepare a Poverty Reduction Strategy Paper (PRSP). PRSPs are also required to obtain debt relief under the HIPC Initiative. The PRSP is merely a renamed Policy Framework Paper, and the conditions are the same: 'It is broadly true that the core macro-economic and structural elements of the early PRSPs have changed little from the programs of the recent past' (IMF and IDA [International Development Associations], 2002). In fact, the PRSP Sourcebook of the Bank advocates 'establishing policies that encourage competitive and efficient services sectors, such as allowing entry where possible and encouraging foreign direct investment'. ${ }^{30}$ In other words, as a matter of policy, PRSPs will promote private sector participation in basic services.

Similarly, the World Bank's Private Sector Development Strategy (2002) plans to increase support to the private sector and its participation in the provision of basic services. In addition, it will support a series of regular surveys of the investment climate in developing countries, which will form an essential element in the Bank's approval of PRSPs. ${ }^{31}$ In fact, the private sector strategy paper calls for more effective coordination between its private sector window, the IFC, and its soft loan window, IDA, which only lends to 78 low-income countries. The aim of the coordination is to involve private sector participation in up to $40 \%$ of IDA operations. In other words, through HIPC debt relief conditionality (via PRSP approval) and through regular IDA conditionality for non-HIPCs - rather than through any national ownership of policies - private sector participation is to be encouraged in low-income countries.

That there is an interlocking set of conditionalities - between IDA, IFC and the IMF - in respect of private sector participation in basic services is clear from the above, as well as IFC's own paper setting out new strategic priorities (IFC, 2002a). The IFC, according to this strategy, will now focus on frontier areas where there is at present little available capital and frontier countries that receive limited private capital from abroad. With this in view, in September 2001, the IFC established a separate Health and Education 
Department. The IFC will promote private sector health involvement in India and Pakistan in South Asia; in the Philippines and China in East Asia; in Kazakhstan, Poland, Romania and Russia in Central/East Europe (CEE)/ CIS; in Cote d'Ivoire, Kenya, Nigeria, South Africa in Sub-Saharan Africa; in Egypt and Turkey in the Middle East; and, in Brazil, Colombia and Mexico in Latin America. This is despite the common knowledge that IFC investments in the past have responded to existing patterns of demand from the affluent sections of the population in any country. ${ }^{32}$

\section{Conclusions}

In summary, despite the mixed experience with the private sector in school education, the definitely harmful experience with privatization and with private sector growth in health services, and the controversial developments in private-public partnerships in the water and sanitation sectors in low- and middle-income countries, there is relentless pressure from all international agencies - through interlocking conditionalities and other means - to promote the growth of the private sector in basic social services, and where possible privatization of public services. This pressure, which signals that the Washington Consensus is alive and rejuvenated, tends to ignore the historical experience of industrialized countries as well as that of high-achiever developing countries in education, health and water/sanitation.

There are indeed circumstances where the private sector's role in education can be complementary to that of the public sector. Allowing private schools can help in certain circumstances - particularly if governments have trouble, on account of fiscal constraints, meeting the full costs (building schools, paying teacher salaries) required to achieve universal primary schooling. It is imperative, in these cases, to ensure that children from poor families unable to pay school fees are able to attend private schools. Thus in this manner there is scope for promoting complementarity between the public and private sectors. However, the evidence provided above does not support the view that private schools are more efficient or of higher quality.

There has been a deliberate effort to promote privatization in health services. But the evidence on the private sector in health services can be summarized thus. On efficiency/quality, the evidence on standards in the private sector relative to the public sector is inconclusive. At the same time, imperfect information on the part of patients may lead to severe market failures in health care services. On increased resources for health, government commitment to maintaining existing public finance levels is essential if total health resources are to increase with greater private sector entry. Private provision has also tended to raise costs. Finally, while consumer choice increases as a result of private provision, the implications for consumer welfare are ambiguous. 
In the water and sanitation sector, while there is no question that public services in water supply, water treatment, waste water treatment and sewerage could not continue in the manner that they have been traditionally run, the evidence does not suggest that wholesale privatization has been very successful at achieving the social and economic objectives. In other words, the experience also suggests that while financial sustainability is important, financial profitability is not necessarily the only or main goal of water and sanitation services.

Where local institutions and the local private sector are weak, public sector provision of water and sanitation services will remain important. In the role of provider, the government is best able to ensure equity, wide coverage, economies of scale, and multisectoral coordination (synergies). At the same time, the role of the community in management will need to be recognized if sustainability of service is to be achieved. Governments can also play a role in strengthening decentralization and facilitating the interface between service providers and service users. In addition, the adoption of appropriate technology is vital for programmes to go to scale in a cost-effective manner. Technology transfer is best accomplished through collaboration between government and the private sector.

It should be noticed that these elements are not included in the simplistic approach of the World Development Report which basically looks at the public provision of basic services as a principal agent problem, and consequently focuses on ease of monitoring and type of contract, eschewing other consideration based on equity and distributional issues, inclusiveness of social policy, and synergies across sectors. Our analytical framework takes these elements into consideration, highlighting practical problems that are otherwise obscured. Moreover, both the actual policy advice of the IFIs as well as its rhetoric show that in the basic social services arena the Washington Consensus still needs to be dethroned.

NOTES

1. In many Latin American countries these were set up prior to World War II.

2. Even Social Safety Nets, which are at best charity and at worst clientelistic, are supposed to be 'prevented from expanding' (see for example Cornia, 2001; Olivier et al., 2004; Tendler, 2002).

3. The rhetorical devices used by the World Bank to present its evidence as scientific are exposed in the Bretton Woods Project (Wilks and Lefrançois, 2003).

4. This is reminiscent of the failed approach in Neoclassical economics to technocratically determine which commodities are public goods and which ones are not (see for example Chang, 2001; Malkin and Wildavsky, 1991).

5. World Bank (World Development Report, 2004: 16).

6. Given the idiosyncratic nature of each privatization process and the quality of data, case studies and thick description seem a more appropriate methodological stance than cross-country econometric studies (Geertz, 2000). 
7. This does not imply that users have to pay the full cost, as the revenue could come from general taxation. In that case fairness, ease of management, and political compromise may indicate that basic services should be free to all, including those who could pay. In this case, progressivity should be achieved through taxation.

8. In other words, state providers that behave like for-profit companies will cause the same problems that arise from the market approach.

9. Also Switzerland and the Netherlands.

10. For a detailed examination of the adequacy, efficiency and equity of the public spending pattern in relation to education for the high-achiever countries, see Mehrotra (1998).

11. See the World Bank's (1997) World Development Report (on the role of the state), and the World Bank's (2000-1) World Development Report (on attacking poverty).

12. See also Parry (1997).

13. Although studies of satisfaction levels with public sector health services are limited, Iriart et al. (2001) report 10 citations concerning satisfaction in Latin America. Five studies about users' satisfaction with public sector primary care clinics showed high levels of satisfaction; another study about a public sector home-care programme also showed satisfaction was high; three articles provided data that show high levels of satisfaction with public hospitals; of two studies on satisfaction with nursing services, one found high satisfaction and the other low satisfaction on several indicators.

14. As expected, given the framework in section 2 .

15. This and the previous paragraph show, as mentioned in section 2, that for-profit services neither increase quality nor reduce unit costs.

16. Juti and Katko (forthcoming) describe the historical experience of private provisioning of water in European cities.

17. A very good conceptual discussion of the different meanings of these partnerships can be found in Mitchell-Weaver and Manning (1991-2).

18. Many of these -2350 of them - have operating PPPs, according to Franceys (2001).

19. For a detailed analysis of the various types of private participation in the provision of water services, see Lee and Jouravlev (1997).

20. PPPs have led to impressive profits in the UK for the companies involved (12\% return on capital when borrowing at perhaps $7 \%$ with $20-40 \%$ gearing), a level much higher than France and the Netherlands. To limit the possibility of abuse of the monopoly position in meeting a basic need, England and Wales introduced three regulators.

21. In high-income countries, BOT, concession contracts, divestiture (i.e. purchase at a discount) and partial divestiture, and outright purchase account for nearly $70 \%$ of all PPP contracts (Franceys, 2001).

22. Now owned by French Suez.

23. Now called Veolia Environnement.

24. Mainly Thames Water, which handles London's water and sewerage, was privatized in 1989 by Mrs Thatcher's government.

25. Given that one of the arguments for privatization is that state companies do not cover their costs (section 1), a guaranteed minimum profit for private providers is the epitome of paradoxes. Moreover, it destroys whatever positive characteristics market provision may have (section 2). If in order to privatize costs are reduced and fees are increased, why not keep the service in state hands when it is 
profitable? This shows that the real issue in the privatization process is one of distribution, not efficiency. In addition, even if state-run companies seek profits the problem is not avoided.

26. Finnegan (2002) notes that the Mayor of Cochacamba insisted with the central government that Misicuni be included, otherwise the leasing of the water system to foreign bidders would be stopped, as it had been in 1997 .

27. For evidence, see a series of reports, examining the pros and cons of various privatizations from around the world in the water sector (http://www.icij.org).

28. The Economist (2004), (3 September) reports: 'The water barons' trouble has sprung not just, or even mainly, from the poor countries' consumers, officials or currency risks, but from their own fast growth, and resultant debt, in rich ones. And that, indeed, is where the biggest recent retreats have been' (p. 58).

29. In Bolivia, SAGUAPAC, in Santa Cruz; in Hungary the city of Debrecen; in Honduras, SANAA.

30. A number of PRSPs already announce government plans for promoting private sector involvement in public service provision in Honduras, Mozambique, Nicaragua and Uganda. The PRSP in Burkina Faso is committed to eliminating monopolies in public utilities, and Nicaragua and Kenya have agreed to increase private sector involvement in water delivery (Marcus and Wilkinson, 2002; Save the Children, 2002).

31. The investment climate will be given attention when there is a possibility of a country receiving finance from the International Development Agency (IDA), the soft loan window of the Bank.

32. For example, in Malawi, IFC has an $18 \%$ share in a 64 -bed hospital, Blantyre, which has been a failure in both financial and health care terms. Thus, as Save the Children (2002) states: ' . . . the private hospital has been unable to achieve even a 20 per cent utilisation rate' (p. 30).

\section{REFERENCES}

Barros, F.C., Vaughan, J.P. and Victora, C. (1986) 'Why so many Caesarean Sections?: The Need for Further Policy Change in Brazil', Health, Policy and Planning 1(1): 19-29.

Bashir, S. (1997) 'The Cost Effectiveness of Public and Private Schools: Knowledge Gaps, New Research Methodologies, and an Application in India', in C. Colclough (ed.) Marketizing Education and Health Developing Countries. Oxford: Clarendon Press.

Bennett, S. (1997) 'Private Health Care and Public Policy Objectives', in C. Colclough (ed.) Marketizing Education and Health Developing Countries. Oxford: Clarendon Press.

Bennett, S. and Tangcharoensathien, V. (1994) 'A Shrinking State: Politics, Economics and Private Health Care in Thailand', Public Administration and Development 14(1): $1-17$.

Berman, P. and Rose, L. (1996) 'The Role of Private Providers in Maternal and Child Health and Family Planning Services in Developing Countries', Health Policy and Planning 11(2): 142-55.

Bloom, G. (1997) 'Financing Rural Health Services: Lessons from China', in C. Colclough (ed.) Marketizing Education and Health Developing Countries. Oxford: Clarendon Press. 
Chang, H. (2001) 'Breaking the Mould: An Institutionalist Political Economy Alternative to the Neoliberal Theory of the Market and the State', UNRISD Social Policy and Development Programme Paper No. 6. Geneva.

Colclough, C. (1997) Marketizing Education and Health in Developing Countries: Miracle or Mirage? Oxford: Clarendon Press.

Cornia, G.A. (2001) 'Social Funds in Stabilization and Adjustment: A Critique', Development and Change 32(1): 1-32.

Cowen, B. and Penelope, J. (1997) 'Getting the Private Sector Involved in Water: What to Do in the Poorest of Countries', Viewpoint Note No. 102, World BankFinance Private Sector and Infrastructure Network, http://www.worldbank.org/ html/fpd/notes/102/102summary.html

Cox, D. and Jimenez, E. (1991) 'The Relative Effectiveness of Private and Public Schools: Evidence from Two Developing Countries', Fournal of Development Economics 34(1): 99-121.

Deolalikar, A. and Vashishta, P. (1996) 'The Health and Medical Sector in India: Potential Reform and Problem'. Centre on Institutional Reform and the Informal Sector (IRIS), University of Maryland, USA. India Working Paper no.9.

Dreze, J. and Sen, A. (eds) (1989) Hunger and Public Action. Oxford: Clarendon Press.

Fine, B. (2001) 'Neither the Washington nor the post-Washington Consensus', in B. Fine, C. Lapavitsas and J. Pincus (eds) Development Policy in the Twenty-First Century. London: Routledge.

Finnegan, W. (2002) 'Leasing the Rain: The World is Running out of Fresh Water, and the Fight to Control it has Begun', letter from Bolivia, The Conde Nast Publications, Inc., The New Yorker (8 April).

Fishlow, A. (1966) 'Levels of Nineteenth Century American Investment in Education', Journal of Economic History 26(4): 418-36.

Franceys, R. (2001) 'Patterns of Public Private Partnerships', paper presented at the Regional Conference on The Reform of the Water Supply and Sanitation Sector in Africa: Enhancing Public-Private Partnership in the Context of the Africa Vision for Water (2025), Kampala, Uganda, 26-8 February.

Geertz, C. (2000) The Interpretation of Cultures: Selected Essays. New York: Basic Books.

Green, A. (1990) Education and State Formation, the Rise of Education Systems in England, France and in the USA. New York: St Martins Press.

Hao, Y., Suhua, C. and Lucas, H. (1997) 'Equity in the Utilization of Medical Services: A Survey in Poor Rural China', IDS BULLETIN: 28(1).

International Finance Corporation (IFC) (2002a) IFC Strategic Directions. Washington, DC: IFC.

International Finance Corporation (IFC) (2002b) Investing in Private Health Care: Strategic Directions for IFC. Washington, DC: IFC.

Iriart, C., Elias, E.M. and Waitzkin, H. (2001) 'Managed Care in Latin America: The New Common Sense in Health Policy Reform', Social Science \& Medicine 52(8): 1243.

Iyer, A. and Sen, G. (2000) 'Health Sector Changes and Health Equity in the 1990s in India', in S. Roghuram (ed.) Health and Equity: Technical Report Series 1.8. Bangalore, India: HIVOS.

Jimenez, E. and Lockheed, M. (1995) 'Public and Private Secondary Education in Developing Countries: A Comparative Study', World Bank Discussion Paper No. 309. Washington, DC: World Bank.

Jimenez, E., Lockheed, M., Luna, E. and Paqueo, V. (1991a) 'School Effects and Costs for Private and Public Schools in the Dominican Republic', International fournal of Educational Research 15 (special issue): 393-410. 
Jimenez, E., Lockheed, E., and Paqueo, V. (1991b) 'The Relative Efficiency of Private and Public Schools in Developing Countries', World Bank Research Observer 6: 205-18.

Juti, P. and Katko, T. (2004) City in Time, Watertime project report, funded by the EU, coordinated by PSIRU (Public Services International Research Unit), University of Greenwich.

Kremer, M. (2003) 'Evidence from a Study of Vouchers for Private Schooling in Colombia', Background Paper for the World Bank World Development Report 2004, World Bank.

Lee, T.R. (2002) 'Improving the Management of Water Supply and Sanitation Systems in Latin America', in The Water Page, URL (consulted 23 April 2005): http://www.thewaterpage.com/ppp_debate_5_terence_lee.htm.

Lee, T.R. and Jouravlev, A. (1997) 'Private participation in the provision of water services', (LC/L. 1024), Medio Ambiente y Desarrollo\#2. Santiago de Chile: ECLAC.

Lei Kremer, M., Muralidharan, K., Chaudhury, N., Hammer, J. and Rogers, H. (2004) 'Teacher Absence in India', Working Draft, World Bank, Washington, DC, accessed 1 September 2004, http://www.worldbank.org

Leipziger, D. and Foster, V. (2003) 'Is Privatisation Good for the Poor', International Finance Corporation, Washington, DC, http://www.ifc.org/publications

Lindert, P.H. (2004) Growing Public: Social Spending and Economic Growth since the Eighteenth Century. Cambridge: Cambridge University Press.

Lobina, E. and Hall, D. (1999) 'Public Sector Alternatives to Water Supply and Sewage Privatisation: Case Studies', PSIRU Report, paper presented at IX Stockholm Water Symposium, 9-12 August.

Malkin, J. and Wildavsky, A. (1991) 'Why the Distinction Between Private and Public Goods should be Abandoned', Fournal of Theoretical Politics 3(4): 355-78.

Marcus, R. and Wilkinson, J. (2002) Whose Poverty Matters? Vulnerability, Social Protection and PRSPs. London: Childhood Poverty Research and Policy Centre.

Mason, E., Kim M.J., Perkins, D., Kim, K.S., and Cole, D. (1980) The Economic and Social Modernization of the Republic of Korea. Cambridge, MA: Harvard University Press.

Mehrotra, S. (1997) 'Health and Education Policies in High-Achieving Countries: Some Lessons', in S. Mehrotra and R. Jolly (eds) Development with a Human Face. Experiences in Social Achievement and Economic Growth (pp. 63-110). Oxford: Clarendon Press.

Mehrotra, S. (1998) 'Education for All: Policy Lessons from High Achieving Countries', International Review of Education 44(5-6): 461-84.

Mehrotra, S. (2002) Basic Social Services for All?: Ensuring Accountability Through Deep Democratic Decentralisation. New York: UNDP, URL (consulted 21 January 2005): http://www.hdr.undp.org/publications

Mehrotra, S. and Delamonica, E. (forthcoming) Public Spending for the Poor: Getting the Fundamentals Right on Social and Macro-Economic Policy. Oxford: Oxford University Press.

Mehrotra, S. and Jolly, R. (eds) (1997) Development with a Human Face: Experiences in Social Achievement and Economic Growth. Oxford: Clarendon Press.

Mehrotra, S., Panchamukhi, P.R., Srivastava, R. and Srivastava, R. (2005) Financing Elementary Education in India: Uncaging the Tiger Economy. New Delhi: Oxford University Press.

Mills, A. (1997) 'Improving the Efficiency of Public Sector Health Services in Developing Countries: Bureaucratic versus Market Approaches', in C. Colclough 
(ed.) Marketizing Education and Health Developing Countries. Oxford: Clarendon Press.

Mitchell-Weaver, C. and Manning, B. (1991-2) 'Public-Private Partnerships in Third World Development: A Conceptual Overview', Studies in Comparative International Development 26(4): 45-67.

Nittayaramphong, S. and Tangcharoensathien, V. (1994) 'Thailand: Private Health Care Out of Control?', Health Policy and Planning 9(1): 31-40.

Normand, C. (1997) 'Health Insurance: A Solution to the Financing Gap?', in C. Colclough (ed.) Marketizing Education and Health Developing Countries.

Olivier, M., Fourie, E. and Nyenti, M. (2004) 'Law as a Tool in Addressing Poverty: Social Protection Perspectives, with Particular Reference to Sub-Saharan Africa', Background Document, Workshop on Law and Poverty IV, CROP and Center for International and Comparative Labour and Social Security Law. Johannesburg, South Africa.

Parry, T.R. (1997) 'Achieving Balance in Decentralization: A Case Study of Education Decentralization in Chile', World Development 25(2): 211-25.

Ramalingaswami, V. (1995) 'Foreword', in Rohde, J.E. and Viswanathan, H. (eds) The Rural Private Practitioner. New Delhi: Oxford University Press.

Rohde, J.E. and Viswanathan, H. (1995) The Rural Private Practitioner. New Delhi: Oxford University Press.

Sanderson, M. (1983) Education, Economic Change and Society in England, 1780-1870. London: Macmillan.

Save the Children (2002) Globalisation and Children's Rights: What Role for the Private Sector? London: Save the Children.

Standing, G. (2000) 'Brave New Words: A Critique of Stiglitz's World Bank Rethink', Development and Change 31: 737-63.

Stephens, W.B. (1998) Education in Britain, 1750-1914. New York: St Martin's Press. Stiglitz, J. (1998) 'More Instruments and Broader Goals: Moving Toward the PostWashington Consensus', World Institute for Development Economics Research (WIDER), Annual Lecture 2, Helsinki, Finland, 7 January.

Tendler, J. (1997) Good Governance in the Tropics. Baltimore, MD: Johns Hopkins University Press.

Tendler, J. (2002) 'Why Social Policy is Condemned to a Residual Category of Safety Nets and What to Do about It', mimeo. Geneva: UNRISD.

Tornqvist, N., Wenngren, B., Nguyen, T.K.C. et al. (2000) 'Antibiotic Resistance in Vietnam: An Epidemiological Indicator of Inefficent and Inequitable Use of Health Resources', in P. M. Hung, I.H. Minas, Y. Liu, G. Dalgren and W.C. Hsiao (eds) Efficient Equity-Oriented Strategies for Health: International Perspectives - Focus on Vietnam. Centre for International Mental Health, University of Melbourne.

Trawick, P. (2003) 'Against the Privatization of Water: An Indigenous Model for Improving Existing Laws and Successfully Governing the Commons', World Development 31(6): 977-96.

UNICEF (1995) A UNICEF Strategy for the Water and Sanitations Sector. New York: Executive Board, UNICEF.

Van Lerberghe, W., Coneceicao, C., Van Damme, W. and Ferrinho, P. (2002) 'When Staff is Underpaid: Dealing with Individual Coping Strategies of Health Personnel', Bulletin of the World Health Organization 80(7): 581-4.

Velasquez, G., Madrid, Y. and Quick, J. (1998) 'Health Reform and Drug Financing: Selected Topic - Health Economics and Drugs', DAP Series No. 6, WHO/DAP/ 98.3. Geneva: World Health Organization. 
Water and Environmental Health at London and Loughborough (WELL) (1999) 'Study, "Public-Private Partnership and the Poor: An Initial Review", Task No. 164 (M. Webster and K. Samsom, eds), March, Loughborough University, UK, http://www.lboro.ac.uk/well/

Webster, M. and Sansom, K. (1999) 'Public-Private Partnership and the Poor: An Initial Review', WELL Study, Loughborough University, UK, URL (consulted 10 December 2004): http://www.lboro. ac.uk/well/

Whitehead, M., Dahlgren, G. and Evans, T. (2001) 'Equity and Health Sector Reforms: Can Low-Income Countries Escape the Medical Poverty Trap?', The Lancet 358(9284): 833-6.

World Bank (1987) Financing Health Services in Developing Countries: An Agenda for Reform. A World Bank Policy Study: Washington, DC.

World Bank (1993) World Development Report: Investing in Health. Oxford: Oxford University Press.

World Bank (1997) World Development Report. Oxford: Oxford University Press.

World Bank (2001) World Development Report: Attacking Poverty. Oxford: Oxford University Press.

World Bank (2002) Private Sector Development Strategy. Washington, DC.

World Bank (2003) World Development Report: Making Services Work for Poor People. Oxford: Oxford University Press.

World Development Report (2004) Making Services Work for Poor People. Washington DC: World Bank and Oxford University Press.

World Health Organization (WHO) (2000) World Health Report. Geneva: WHO.

Yang, B.M. (1993) 'Medical Technology and Inequity in Health Care: The Case of Korea', Health Policy and Planning 8(4): 385-93.

RÉSUMÉ

\section{Le Secteur Privé et la Privatisation des Services Sociaux: Le Consensus de Washington, est-il Mort?}

Parmi les événements les plus significatifs des années 90 dans le développement de politiques sociales aux pays en voie de développement et en transition on trouve la croissance de privatisations dans les domaines de la santé, l'éducation et l'approvisionnement d'eau. Ce sont des services sociaux basiques où les MDG sont fortement impliqués. Le pluralisme dans les services d'assistance a été dans une grande mesure un élément fondamental du Consensus de Washington. Malgré la prédique de la morte du Consensus de Washington depuis plusieurs ans, les institutions financières internationales ont poussé le pluralisme dans les services sociaux depuis les années 90. Cet article examine en partie l'évidence concernant le secteur privé et les privatisations de ces trois services sociaux pendant les années 90, et jette un regarde critique aux arguments pour une participation augmentée du privé dans l'approvisionnement de ces services. L'article examine le rôle que le privé peut ou doit jouer dans l'approvisionnement de services sociaux dans les pays en voie de développement et conséquemment trouve sa raison d'être dans des préoccupations politiques d'un ordre pratique. Pour des raisons d'espace, cet article ne verse pas sur l'approvisionnement de services sociaux basiques par des organisations au but non lucratif ou par des ONG dont le rôle dans la plus part de pays est assez réduit. 
RES UMEN

\section{El Sector Privado y la Privatización de los Servicios Sociales: ¿Ha Muerto el Consenso de Washington?}

Uno de los acontecimientos más significativos de los años 90 en el desarrollo de políticas sociales en los países en desarrollo y en transición fue el crecimiento de las privatizaciones en salud, educación y suministro de agua, tres servicios básicos que involucran a los MDG. El pluralismo en servicios asistenciales constituyó en gran medida un elemento fundamental del Consenso de Washington. A pesar de que se pregona que el Consenso de Washington murió hace años, las instituciones financieras internacionales han estado propugnando el pluralismo del bienestar social como parte de los servicios sociales desde los 90. Este artículo examina parte de la evidencia con relación al sector privado y la privatización en estos tres servicios sociales durante los años 90 y examina críticamente los argumentos formulados en favor de una mayor participación del sector privado en el suministro de estos servicios. El documento trata el papel que el sector privado podría o debería desempeñar en el suministro de servicios sociales básicos en los países en desarrollo y por tanto encuentra su motivación en preocupaciones prácticas de política. Por razones de espacio este artículo no se ocupa del suministro de servicios sociales básicos por parte de organizaciones sin fines de lucro u ONG que en la mayor parte de países son una parte pequeña del sector.

\section{BIOGRAPHICAL NOTES}

SAntosh mehrotra is Senior Economic Advisor, Asia Bureau, UNDP, Bangkok, and was earlier Senior Policy Adviser to the Human Development Report. He also led UNICEF's research programme on developing countries at Innocenti Research Centre, Florence. His books include: India and the Soviet Union: Trade and Technology Transfer (Cambridge UP, 1990), Development with a Human Face (Oxford UP, 1997). Four co-authored books are forthcoming: Public Spending for the Poor, Universalizing Elementary Education in India (both Oxford UP), The Economics of Elementary Education in India, and Asian Informal Workers in the Value Chain. Please address correspondence to: Santosh Mehrotra, Regional Economic Adviser, Poverty and Governance, UNDP Regional Centre for Asia, Bangkok.

EnRIQue Delamonica is a policy analyst in the Division of Policy and Planning of UNICEF headquarters working on the financing of social services, international development and poverty reduction strategies, socio-economic disparities, and the impact of macro-economic trends on children. He has also lectured on economics and development at New York University, Columbia University, the Institute for Social and Economic Development (Argentina), and the New School University. Please address correspondence to: Enrique Delamonica, Policy Analyst, Division of Policy and Planning, UNICEF, 3 UN Plaza, New York, NY 10017, USA. [email: edelamonica@unicef.org] 